\title{
Influence of Applying Infiltration and Retention Objects to the Rainwater Runoff on a Plot and Catchment Scale - Case Study of Służewiecki Stream Subcatchment in Warsaw
}

\author{
Mariusz Barszcz* \\ Department of Hydraulic Engineering, Warsaw University of Life Sciences - SGGW, \\ Nowoursynowska 159, 02-776 Warsaw, Poland
}

Received: 2 March 2014

Accepted: 3 September 2014

\begin{abstract}
This article presents the results of an analysis aimed at determining the influence of applying selected types of objects for the infiltration and retention of rainwater (LID - low impact development objects), on a plot scale (area of a shopping mall) and in the subcatchment of Służewiecki Stream in Warsaw, on the characteristics of surface runoff/outflow as well as retention and infiltration depths, in response to a single rainfall event. The following types of objects were accounted for in the study: permeable soil layer, green roof, permeable paved parking lot surface, and infiltration trench. The SWMM model (storm water management model), designed by the U.S. Environmental Protection Agency was used to carry out simulation calculations for the individual scenarios of applying infiltration and retention objects on a plot and catchment scale. The effect of applying LID objects throughout the analyzed area was, in both cases, a reduction in the depth of surface runoff, outflow volume and, at the same time, an increase in the infiltration and retention depths. The most significant reduction in surface runoff on the plot scale (approximately 99\%) occurred in the case of calculation scenarios calling for the application of infiltration trenches (scenario LID3), as well as permeable layers of soil and gravel (LID5 and LID6). The most significant reduction in runoff/outflow on the catchment scale was achieved by the combined application of objects of "permeable soil layer" and so-called "green roofs" (LID5). The reduction in the runoff depth and peak flow rate amounted to 50.0 and $38.5 \%$, respectively, as compared to runoff from the catchment at the current state of its urbanization. The influence of urbanization that the plot of land and subcatchment area had undergone between 1970 and 2005 also was analyzed. The increased urbanization of the catchment, determined as $40 \%$, resulted in an increase in the maximum flow rate in the "Rosola" profile (approximately 19 times higher), as well as outflow volume (approximately 39 time higher).
\end{abstract}

Keywords: urbanization, SWMM model, LID objects, retention and infiltration of rainwater, surface runoff reduction

*e-mail: mariusz_barszcz@sggw.pl 


\section{Introduction}

Economic development and an ever-increasing human population play an important role in the growth of urbanized areas and thus the amount of sewered impermeable areas. Progressing urbanization leads to an increase and acceleration in the surface runoff of rainwater (resulting in flooding) along with a decrease in the infiltration of water to soil (leading to a reduction in the resources of groundwater and, in consequence, the degradation of water ecosystems). One means of protecting people and their property from flooding, as specified in the Water Law Act [1], is maintaining, creating, and recreating water retention systems. Plans regarding the management of flood risk indicate the limitation of sealed (paved) areas, stop or deceleration of rainwater runoff to the sewage system or other receivers (e.g., rivers), and an increase in the amount of green areas as the most important measures for protecting and increasing water retention in urbanized areas. The significance of actions aimed at increasing retention in catchments also has been acknowledged within the scientific studies program BIOSTRATEG [2], which includes "the rational management of natural resources with particular attention paid to water management" as one of its five strategic problem areas.

The article presents the analysis of how applying selected types of objects for infiltrating and retaining rainwater (permeable soil layer, green roof, permeable paved parking lot surfaces, and infiltration trenches), on a single plot scale (encompassing the area of a shopping mall) and in the subcatchment of Służewiecki Stream, influences the characteristics of surface runoff/outflow, as well as retention and infiltration depths. The idea behind applying such objects is to stop rainwater at the spot where runoff forms, by the retention, infiltration, interception, and evapotranspiration of as much water as possible, rather than by channeling rainwater into the sewage system [3]. The benefits of applying such objects include not only restricting surface water runoff (reducing the risk of flooding), but also replenishing groundwater and limiting the drainage of pollutants into sewage water. An in-depth description of the methods of managing rainwater which can be applied in urbanized areas on three scales, i.e., plots of land, neighborhoods, and catchments, has been presented in another work of the author [4]. A description of efforts aimed mainly at retaining runoff also can be found in a publication by Żbikowski and Żelazo [5]. Objects used for the infiltration and retention of rainwater and distributed throughout a given area are shortly referred to as LID (low impact development) objects, in accordance with terminology used in other articles [6-8]. The present study also presents the analysis of the influence of the increased urbanization of the analyzed catchment in 1970-2005 on runoff.

Analyses in the present work were carried out using the Storm Water Management Model (SWMM) model for a plot of land and catchment in reaction to a single rainfall event. Results of similar analyses found in publications usually pertain only to small areas in a catchment or factor for continual (long-term) rainfall events in their calcula- tions $[9,10]$. The analyses allowed new information regarding the influence of infiltration and retention objects on the values of hydrological characteristics on a catchment scale to be obtained. Simulations were performed for rainfall with a depth of $14.5 \mathrm{~mm}$ and duration of $40 \mathrm{~min}$., which had been registered in the given catchment. The results of this rainfall were local flooding. Based on calculations using a formula provided by Błaszczyk et al. [11], the probability of such a rainfall was calculated at approximately $30 \%$. Practical issues influenced choosing a single rainfall event characterized by a probability that falls in the range of 10 to $50 \%$ since flows caused by rainfalls with such probabilities are used in engineering to design technological objects for water management in urbanized areas [12-14]. The reason behind accepting for analysis a single rainfall event, which resulted in flooding in the analyzed catchment, was i.e. to establish the degree to which the maximum flow rate and outflow volume are reduced when applying objects for the infiltration and retention of rainwater in the catchment. This made it possible to assess whether applying these types of objects within the catchment can serve as a means of limiting flood risk in the given catchment as well as other urbanized catchments of similar characteristics.

\section{Służewiecki Stream Catchment}

The case study was conducted on the urbanized subcatchment of Służewiecki Stream, located within the Ursynów district in the southern part of Warsaw (Fig. 1). Its surface area is $4.5 \mathrm{~km}^{2}$, while the whole catchment, up to the "Rosoła" water guage station, is characterized by a total area of $43.0 \mathrm{~km}^{2}$. Służewiecki Stream is a partially open and partially closed channel into which water is drained by a sewage network.

Impermeable surfaces constitute approximately $40 \%$ of the area in the analyzed subcatchment; moreover, the subcatchment is nearly completely sewered. These two factors combined result in this region having a very strong influence on how flows in Służewiecki Stream are shaped. The influence of the "Rów Grabowski" subcatchment on flows in the "Rosoła" profile is relatively low due to the lack of a sewage system, whereas the low influence of the "Okęcie" catchment stems from the presence of storage reservoirs with a total capacity of $42,900 \mathrm{~m}^{3}$ [15].

\section{Methods of Analysis Using the SWMM Model}

SWMM version 5.0.22 designed by the U.S. Environmental Protection Agency (EPA), was used to model the influence of applying objects for the infiltration and retention of rainwater distributed throughout the analyzed catchment on runoff. SWMM is a dynamic model designed to stimulate the runoff of water and contaminants in response to single or continuous rainfall events. An indepth description of the model can be found in the author's previous work [15]. 


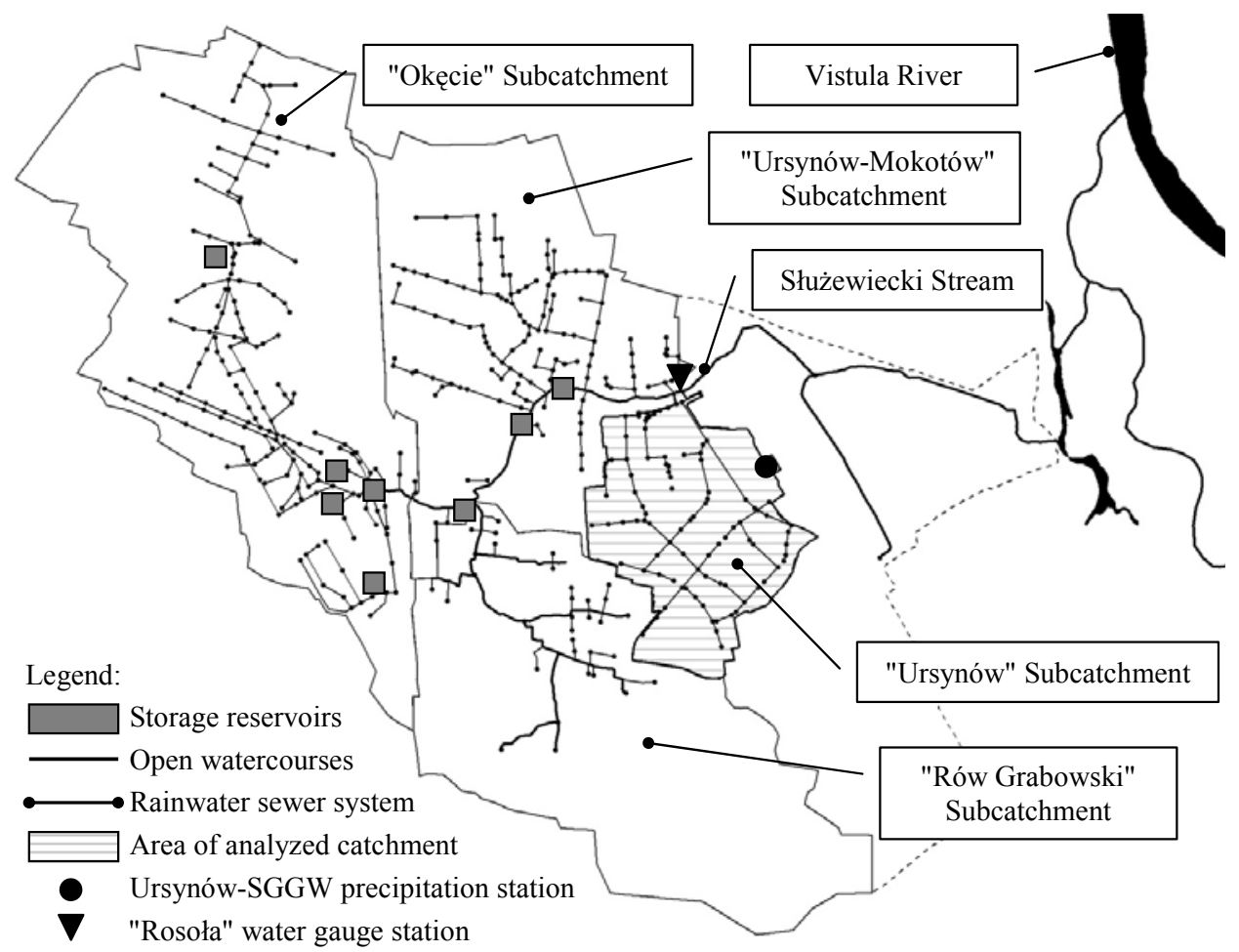

Fig. 1. Borders of subcatchment areas as well as the location of precipitation and water gauge stations.

The calculation procedure of the model is based on the collection of partial areas with given attributes (which constitute homogeneous areas with various types of land use, chosen from the catchment in order to account for the spatial variation of the modeled hydrological processes), which transform the rainfall hitting their surface into runoff. The produced runoff is then transported to the outfall profile of the catchment by its hydraulic system, which consists of a network of sewage pipes, as well as natural and man-made trenches (channels). The dynamic wave equation was used in order to calculate the transformation of runoff in the analyzed catchment, while effective rainfall was determined using the CN-SCS method [16]. Fig. 2 shows the SWMM model of the "Ursynów" subcatchment system divided into homogenous areas characterized by different proportions of impermeable surfaces.

The described model was adapted for eight calculation scenarios on a plot scale, and seven scenarios on a catchment scale, which account for the state of land use in the analyzed areas in 1970 and 2005, as well as various options of applying LID objects for the retention and infiltration of rainwater. The objects selected for analysis were included in the model by defining information in the LID Controls dialog window, which is a characteristic of each subarea isolated within the catchment area. The characteristics of parameters that ought to be accounted for when designing LID objects and during their application in select sub-areas can be found in the SWMM model manual [17].

The three main types of objects applied in the analyses using the SWMM model, the main functions of which were the retention and infiltration of direct rainfall or rainwater runoff from the surface or pipes from neighboring impermeable surfaces are:
- Bio-retention Cells - the main element of these objects is a permeable soil layer characterized by an adequately high filtration coefficient, covered by foliage (serving as a rain garden or green roof); a gravel retention layer may be found in the lower part.

- Infiltration Trenches - infiltration trenches filled with an absorbent layer of gravel.

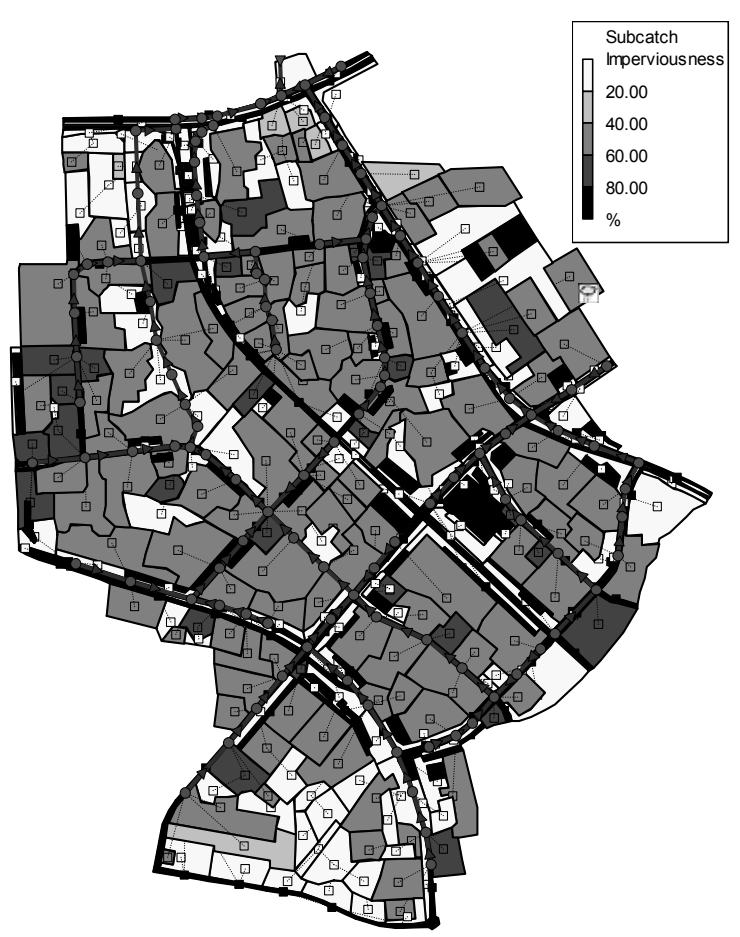

Fig. 2. SWMM model of the Ursynów subcatchment divided into homogenous subcatchment areas. 
Table 1. Select characteristics of LID objects assumed in the SWMM model.

\begin{tabular}{|c|c|c|c|c|c|c|}
\hline \multirow{3}{*}{ Type of LID object } & \multirow{2}{*}{$\begin{array}{l}\text { Storage Depth } \\
\text { - Surface L. }\end{array}$} & \multirow{2}{*}{$\begin{array}{l}\text { Thickness - } \\
\text { Soil Layer }\end{array}$} & \multirow{2}{*}{$\begin{array}{l}\text { Height - } \\
\text { Storage Layer }\end{array}$} & \multirow{2}{*}{$\begin{array}{c}\text { Thickness - } \\
\text { Pavement Layer }\end{array}$} & \multicolumn{2}{|c|}{ Conductivity } \\
\hline & & & & & Soil Layer & Storage L. \\
\hline & \multicolumn{4}{|c|}{$[\mathrm{mm}]$} & \multicolumn{2}{|c|}{$[\mathrm{mm} / \mathrm{hr}]$} \\
\hline Permeable paved surface (porous pavement) & 1.4 & - & 400 & 100 & - & 750 \\
\hline Infiltration trench & 1.4 & - & 1,5 & - & - & 750 \\
\hline Permeable soil layer (bio-retention cells) & 2.5 & 400 & 150 & - & 120 & 750 \\
\hline
\end{tabular}

- Porous Pavement (Block Paver) - objects which facilitate or accelerate the infiltration of rainwater into the ground on hardened surfaces through the application of permeable surfaces (e.g., openwork concrete slabs on parking lots); a layer containing fine gravel or sand may be present in the bottom part.

Applying LID objects in analyses called for indicating values of their characteristics in the SWMM model, which were accepted on the bases of a detailed analysis of information provided in literature $[18,19]$ and proposed in the model manual [17]. Table 1 presents a compilation of the values of select characteristics of LID objects entered in the model, which describe the vertical dimensions and filtration properties of particular layers of these objects. The surface area of the individual objects in the model varied and depended on the size of the area in the specific homogenous subcatchment on which it is actually possible to apply such objects. In the case of analyses for the scenario of applying a "permeable soil layer" (LID5-LID6 on a plot scale and LID3-LID5 on a catchment scale), a retention layer of gravel in the lower part of these objects was additionally accounted for. For objects that served the function of a "green roof" in a given scenario, relatively large depths of the soil and gravel layer were assumed (soil and storage layers), i.e. 400 and $150 \mathrm{~mm}$, respectively.

\section{The Effectiveness of Infiltration and Retention Objects on a Plot Scale}

The implementation of low-impact development objects for infiltrating and retaining rainwater ought to be initiated in areas where rainfall hitting the surface is transformed into surface runoff on a plot of land. The analysis covered a 5.1 ha plot of land located within the Służewiecki Stream subcatchment area developed as a shopping mall (Fig. 3A), for which seven calculation scenarios were prepared. An SWMM image of the property, divided based on the types of land use, has been presented in Fig. 3B.

The first part of the work consisted of analyzing the influence of the increase in urbanization during the period from 1970 (plot of land consisting entirely of arable land) to 2005 on the processes of rainwater runoff/outflow. The second part of the work involved the analysis of the influence of applying LID objects for the infiltration and retention of rainwater on a plot scale on the following features: volume of outflow, runoff, infiltration, and retention depth. The calculations were conducted in response to a rainfall event characterized by a depth of $14.5 \mathrm{~mm}$ and duration of 40 minutes, which was measured at the "Ursynów-SGGW" precipitation station on May 22, 2007. The rainfall depth taken into analysis was similar to the average value for 31
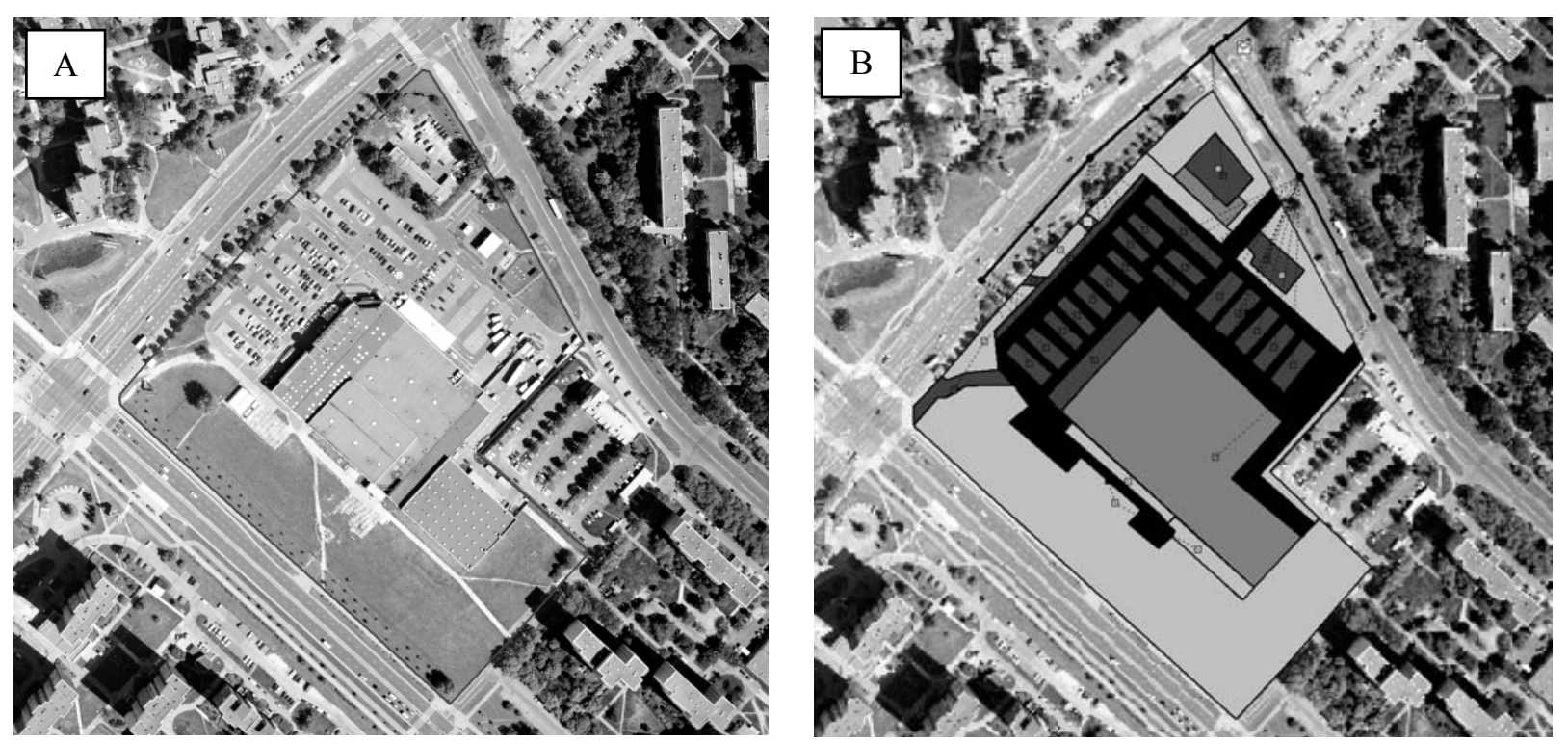

Fig. 3. State of land use of the analyzed plot of land in 2005 (A) and SWMM model view of the same plot (B) (source of aerial photos: CODGiK). 
Table 2. The influence of urbanization and the application of infiltration and retention objects on surface runoff, retention, and infiltration of rainwater on a plot scale.

\begin{tabular}{|c|c|c|c|c|c|c|c|}
\hline \multirow[t]{2}{*}{ Description of scenario - type of drained surface } & \multirow[t]{2}{*}{ Scenario } & 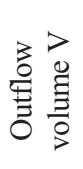 & 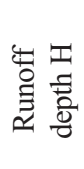 & 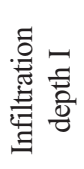 & 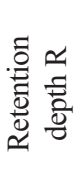 & 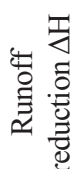 & 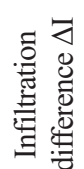 \\
\hline & & {$\left[\mathrm{m}^{3}\right]$} & {$[\mathrm{mm}]$} & [mm] & [mm] & [\%] & [\%] \\
\hline Initial state of $-0 \%$ urbanization & Year 1970 & 7.5 & 0.1 & 13.4 & 0.9 & - & - \\
\hline Current state of $-57.6 \%$ urbanization & Year 2005 & 375.6 & 7.5 & 6.2 & 0.8 & - & - \\
\hline Permeable paved surface - parking lots & LID1 & 268.9 & 5.3 & 8.4 & 0.8 & -28.4 & 35.0 \\
\hline Infiltration trench - roads and parking lots & LID2 & 149.6 & 2.3 & 11.6 & 0.6 & -68.9 & 86.1 \\
\hline Infiltration trench - parking lots, roads, and roof runoff & LID3 & 5.7 & 0.1 & 13.8 & 0.6 & -98.8 & 121.8 \\
\hline Permeable soil layer - roads and parking lots & LID4 & 149.6 & 2.9 & 0.6 & 11.0 & -61.1 & -89.9 \\
\hline Permeable soil layer - roads, parking lots, and green roof & LID5 & 5.7 & 0.1 & 0.6 & 13.8 & -98.5 & -89.9 \\
\hline Permeable soil layer - as above, as well as gravel layer & LID6 & 5.7 & 0.1 & 4.1 & 10.3 & -98.5 & -34.2 \\
\hline
\end{tabular}

of the highest rainfall events in 2006-2008 (equal to 12.0 $\mathrm{mm}$ ), which were included in another study of the author [20].

The following calculation scenarios were included in the analysis that aimed to determine the influence of applying LID objects on the processes of surface runoff/outflow, retention, and infiltration:

LID1 Applying openwork concrete slabs (permeable paved surfaces) in areas covered by parking lots, beneath which there is a layer of gravel and sand

LID2 Constructing infiltration trenches along roadsides and parking lots filled with an absorbent layer of gravel

LID3 Applying infiltration trenches that take in runoff rainwater not only from roads and parking lots, but also from the surface of the shopping mall roof

LID4 Applying a permeable layer of soil covered with grass (without a bottom layer of gravel) in areas of existing lawns, which takes in runoff rainwater from roads and parking lots

LID5 Creating permeable layers of soil in areas of existing lawns (as in the previous scenario) as well as on the surface of the shopping mall roof, which, in this case, functions as a "green roof" (object consisting of two layers: soil and gravel)

LID6 Creating a so-called "green roof" as well as permeable layers of soil in areas of existing lawns, which consist of a top layer of soil and, additionally, a bottom layer of gravel.

The results of the simulations have been compiled in Table 2 as well as presented in the form of a graph (Fig. 4).

As a result of the analysis it was established that the increased urbanization of the analyzed plot between the years 1970 and 2205, amounting to 57\%, caused a very large increase in outflow (approx. 50 times higher) and, at the same time, a reduction in infiltration depth. The volume of the outflow increased from a value of 7.5 to $375.6 \mathrm{~m}^{3}$, and the runoff depth from a value of 0.1 to $7.5 \mathrm{~mm}$.

The analysis, which regarded the application of objects for the infiltration and retention of rainwater within the area of the analyzed plot of land according to the six investigated scenarios, revealed that the realization of each of the scenarios will result in a reduction of surface runoff. Implementing the LID1-LID3 scenarios, which call for using permeable paved surfaces on parking lots and infiltration trenches, will result in increasing infiltration depth. The result of applying permeable layers of soil (scenarios 46) will be an increase in rainwater retention depth.

The highest reduction in surface runoff was achieved by applying infiltration trenches, which take in runoff water from roads, parking lots, and the surface of the shopping mall roof (scenario LID3). The reduction of runoff amounted to $98.8 \%$ in relation to runoff from the plot at the current level of urbanization (scenario: Year 2005). The reduction of runoff was almost the same in the case of scenarios LID5

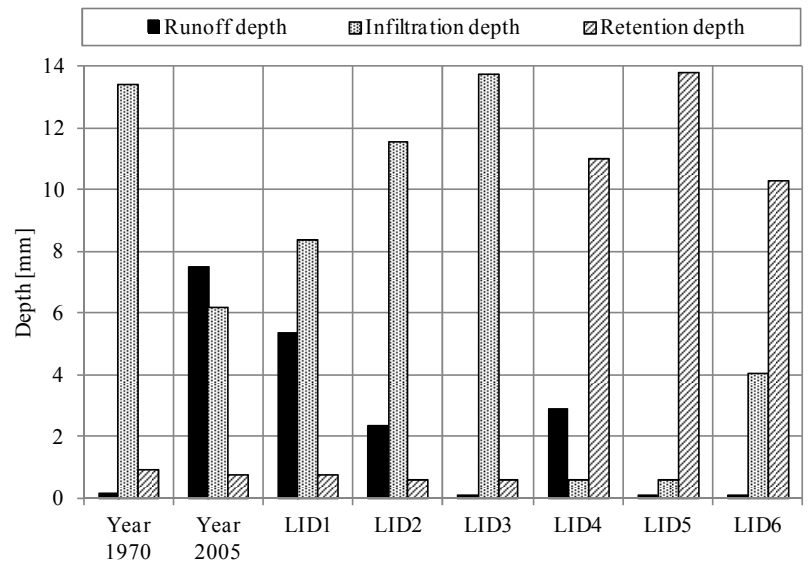

Fig. 4. Influence of calculation scenarios on surface runoff, infiltration, and retention depth on a plot scale. 

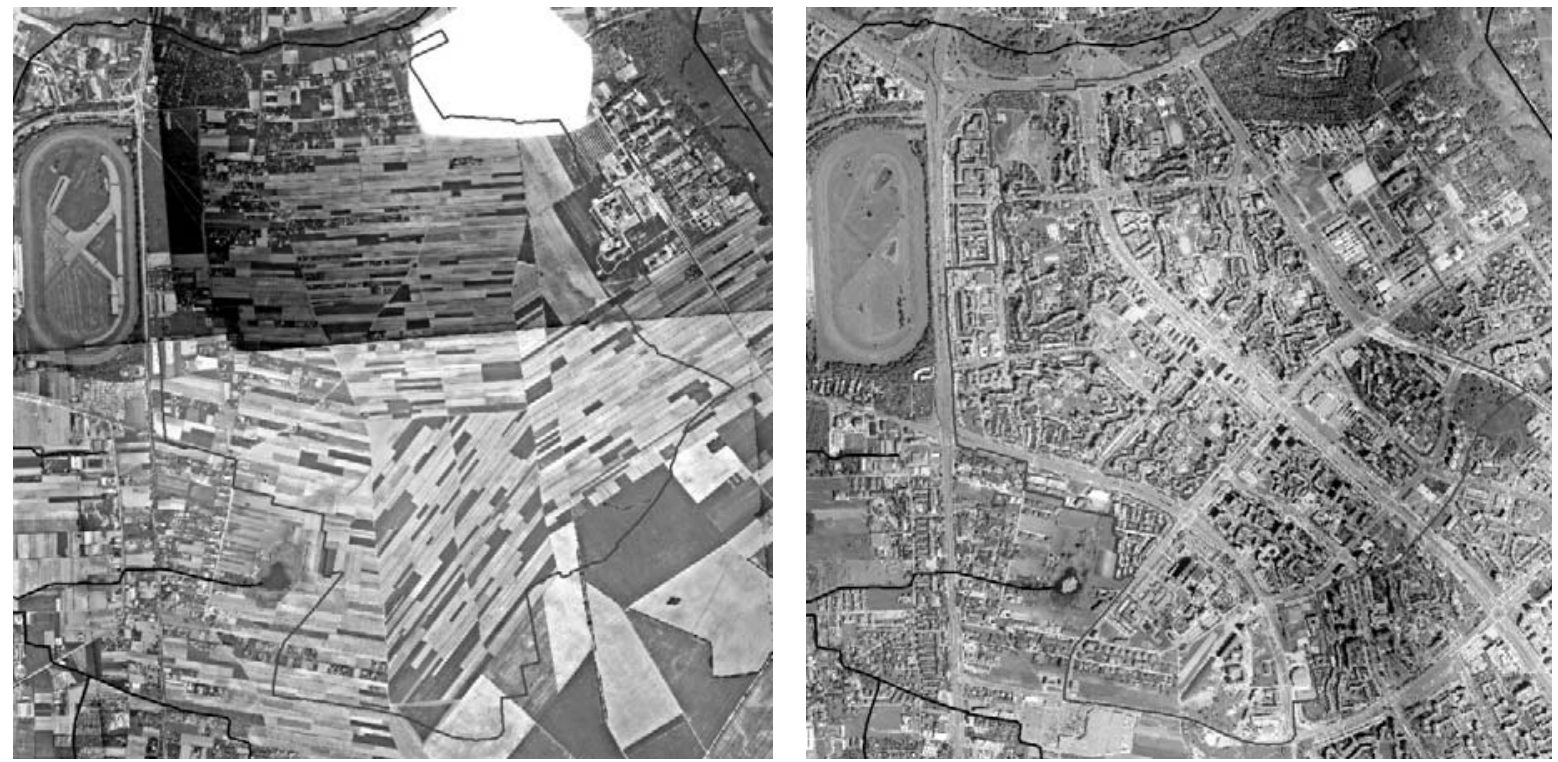

Fig. 5. State of "Ursynów" subcatchment area land use in 1970 and 2005 (source of aerial photographs: CODGiK; orthophotomap: prepared by the author).

and LID6, which anticipate creating permeable layers of soil near roads and parking lots, as well as a so-called "green roof" on the surface of the shopping mall rooftop. The amount of runoff for the three scenarios described above was reduced to the level prior to urbanization. The most significant increase in infiltration depth (121.8\%) was calculated for the LID3 scenario, which calls for creating infiltration trenches. The infiltration depth was higher than for the initial state of use characterizing the plot.

The results of similar analyses presented by Gilroy and McCuen [7] revealed that, on a plot scale, the degree in which runoff is reduced depends on the type of land use, the amount and type of objects applied, as well as the amount of rainfall. By applying rainwater barrels and permeable layers of soil within the area of a residential plot with single-family houses, a $92 \%$ reduction in the volume of runoff was achieved in reaction to a rainfall event with a $100 \%$ probability of occurring $(\mathrm{p}=100 \%)$. Similar analyses for the area encompassing the shopping mall revealed the maximum reduction of runoff to be $73 \%$. The results of field studies conducted by DeBusk and Wynn [21] confirmed the effectiveness of permeable soil layers in the reduction of runoff. The authors showed that they are capable of reducing the volume of runoff and maximum flow rate (peak flow) from the area of a parking lot by 97 and 99\%, respectively. Analyses carried out by Dreelin et al. [22] determined that the application of permeable materials when constructing parking lot surfaces can reduce rainwater runoff by $93 \%$.

\section{The Effectiveness of Infiltration and Retention Objects on a Catchment Scale}

A SWMM model adapted for seven calculation scenarios was used to analyze the influence of the increasing urbanization of the "Ursynów" subcatchment area during the period of 1970 to 2005 , as well as the application of rainwater infiltration and retention objects on the following characteristics: maximum flow rate, outflow volume, runoff, infiltration, and retention depth. Calculations were carried out in response to rainfall characterized by a depth of $14.5 \mathrm{~mm}$ and duration of $40 \mathrm{~min}$. Fig. 5 includes bird'seye view pictures in which the state of land use of the catchment area in the two analyzed time periods has been presented.

The following calculation scenarios were included in the analysis that aimed to determine the influence of LID objects on surface runoff, retention, and infiltration: LID the application of openwork concrete slabs on parking lot surfaces, beneath which there is a layer of gravel and sand; the permeable paved surfaces were accounted for in designated parking lots within the model ranging from 1,300 to $13,100 \mathrm{~m}^{2}$, as well as select residential areas of multi-family housing and commercial areas, under the assumption that the dispersed parking lots cover approx. $10 \%$ of the surface of these areas; LID2 - the application of infiltration trenches along the main roads and parking lots, filled with an absorbent layer of gravel; LID3 - creating permeable soil layers covered by grass along the edges of the main (largest) parking lots and roads (including a strip of greenery (median) separating the roads going in each direction); LID4 - creating permeable soil layers which take in rainwater runoff from the main roads and parking lots as well as from the surface of some roofs of buildings in residential areas with multi-family housing $(10 \%$ of the surface of the selected subareas of the catchment was allotted to creating these objects); LID5 - applying objects forming permeable soil layers along the main roads and parking lots, and creating so-called "green roofs" on the surface of roofs in select residential areas (objects take up approx. $20 \%$ of the given surface area). The percentage of areas in the analyzed subcatchment on which LID objects were applied, as well as the results of the simulation, have been presented in 
Table 3. The influence of urbanization and applying infiltration and retention objects on the surface runoff, retention, and infiltration of rainwater on a catchment scale.

\begin{tabular}{|c|c|c|c|c|c|c|c|c|c|}
\hline \multirow[t]{2}{*}{ Description of scenario - type of drained surface } & \multirow[t]{2}{*}{ Scenario } & $\begin{array}{l}\underset{d}{d} \\
\text { 离 }\end{array}$ & 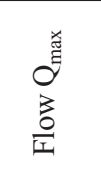 & 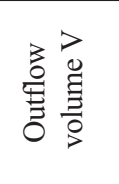 & 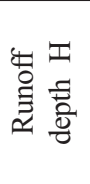 & 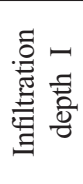 & 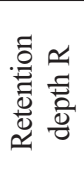 & 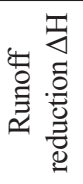 & 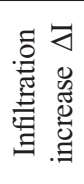 \\
\hline & & {$[\%]$} & {$\left[\mathrm{m}^{3} \cdot \mathrm{s}^{-1}\right]$} & {$\left[\mathrm{m}^{3}\right]$} & {$[\mathrm{mm}]$} & {$[\mathrm{mm}]$} & {$[\mathrm{mm}]$} & {$[\%]$} & {$[\%]$} \\
\hline Initial state of $-1.0 \%$ urbanization & Year 1970 & 0.0 & 0.409 & 750.4 & 0.1 & 13.4 & 0.9 & - & - \\
\hline Current state of $-41.0 \%$ urbanization & Year 2005 & 0.0 & 7.861 & $29,094.0$ & 6.1 & 7.9 & 0.5 & - & - \\
\hline Permeable paved surface - parking lots & LID1 & 8.7 & 6.597 & $22,396.3$ & 4,8 & 9.1 & 0.5 & -20.7 & 16.2 \\
\hline Infiltration trench - main roads and parking lots & LID2 & 1.2 & 6.249 & $19,937.5$ & 4.3 & 9.7 & 0,5 & -29.6 & 23.0 \\
\hline Permeable soil layer - main roads and parking lots & LID3 & 4.3 & 6.266 & $20,301.4$ & 4.4 & 8.7 & 1.4 & -28.0 & 10.6 \\
\hline $\begin{array}{l}\text { Permeable soil layer - as above, as well as runoff from } \\
\text { building rooftops }\end{array}$ & LID4 & 8.0 & 5.546 & $16,797.9$ & 3.6 & 9.0 & 1.9 & -41.1 & 14.3 \\
\hline Permeable soil layer - roads, parking lots, and green roofs & LID5 & 12.1 & 4.832 & $14,265.5$ & 3.0 & 8.9 & 2.5 & -50.0 & 13.4 \\
\hline
\end{tabular}

Table 3. The results of the analysis have also been presented in the form of graphs (Figs. 6 and 7).

As a result of the analyses, it was established that the increased urbanization of the analyzed subcatchment of the Służewiecki Stream in the period from 1970 to 2005, established at $40 \%$, led to a very significant increase in surface runoff/outflow, along with a reduction in the depth of infiltration. The calculated maximum flow rate on the hydrograph of the "Rosoła" profile increased from a value of 0.409 to $7.861 \mathrm{~m}^{3} \cdot \mathrm{s}^{-1}$ (approx. 19 times higher). At the same time, the volume of outflow increased from 750.4 to 29,094.0 $\mathrm{m}^{3}$ (approx. 39 times higher).

Simulation calculations regarding the application of objects for the infiltration and retention of rainwater according to the five analyzed scenarios revealed that the implementation of each of the scenarios will result in a decrease in values of maximum flow rate, outflow volume, and runoff depth, as well as an increase in the depth of infiltration. What is more, implementing scenarios LID3-LID5, which anticipate applying permeable soil layers, will increase rainwater retention depth within the catchment.

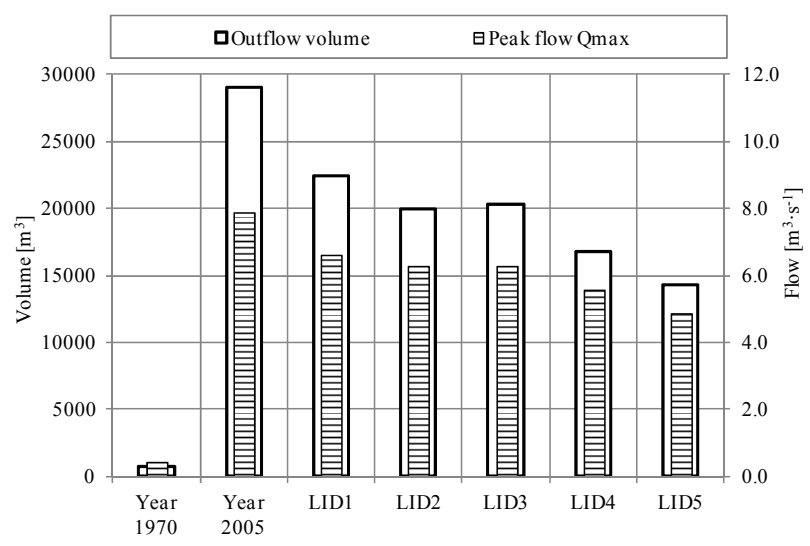

Fig. 6. Characteristics of outflow in the "Rosoła" profile for individual scenarios.
The most significant reduction in surface runoff/ outflow was obtained for the scenario that called for the combined application of permeable soil layers along the main roads and parking lots, as well as the construction of "green roofs" on the roof surfaces of select buildings (LID5). The reduction of runoff depth was equal to $50 \%$ in relation to the runoff from the catchment at the current state of urbanization. The maximum flow rate of the hydrograph decreased from a value of 7.861 to $4.832 \mathrm{~m}^{3} \cdot \mathrm{s}^{-1}(38.5 \%)$. The surface of the catchment area on which LID objects were applied according to this scenario was $12.1 \%$. The smallest reduction in runoff depth and maximum flow rate, equal to 20.7 and $16.1 \%$, respectively, were obtained when applying permeable paved surfaces on some of the parking lots within the catchment (modifying $8.7 \%$ of the catchment area).

The most significant increase in infiltration depth (23.0\%) occurred as a result of applying scenario LID2, which called for creating infiltration trenches along the main roads and parking lots. This scenario accounted for applying such objects on $1.2 \%$ of the surface area of the analyzed catchment.

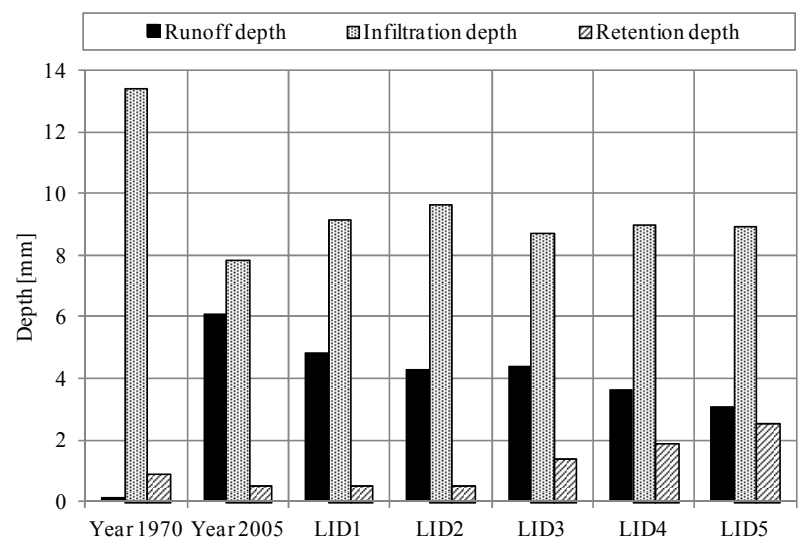

Fig. 7. Influence of calculation scenarios on surface runoff, infiltration and retention depth on a catchment scale. 
A similar analysis [23] conducted using a SWMM model for the area of the Olympic village in Beijing, analyzed the influence of modifying existing infiltration and retention objects on the reduction of runoff. The analysis involved the same kinds of objects as in the present work, but was conducted in response to long-term rainfall events. The modification of objects (changing their parameters) caused the yearly runoff volume to decrease by $27 \%$, whereas the maximum flow rate decreased by $21 \%$ in comparison to the baseline scenario. A SWMM model was also applied when carrying out calculations in another catchment located within China [24]. The most significant reduction of runoff was obtained for scenarios where permeable paved surfaces of roads and parking lots were applied (the reduction amounted to approx. 20\%), and "green roofs" constructed, in reaction to single rainfall events of various depths. The percentage share of the first kinds of objects accepted for analysis ranged from 20 to $80 \%$ of the analyzed subarea, with the second types of objects amounting to as much as $20 \%$, depending on the type of land use. Chapman and Horner [25] showed that applying permeable soil layers along roads within the city of Washington can reduce runoff by as much as $26-52 \%$.

\section{Conclusions}

The work presented the results of an analysis which aimed to determine the influence of applying select types of objects for the infiltration and retention of rainwater (LID objects) on the characteristics of outflow, as well as surface runoff, retention and infiltration depths, on a plot of land (area of a shopping mall) and within the Służewiecki Stream subcatchment area. The following types of objects were included in the analysis: permeable paved surface of parking lot, infiltration trench, green roof, and permeable soil layer. The analysis of how the urbanization of the studied plot of land and subcatchment that took place in the time frame of 1970-2005 influenced runoff/outflow has also been presented. The SWMM model was used to carry out simulation calculations in reaction to an individual rainfall event of $14.5 \mathrm{~mm}$.

The conducted analyses allow us to draw the following conclusions:

- The increase in urbanization of the analyzed plot of land which took place between 1970 and 2005, 57.6\%, led to a very significant increase in the volume of outflow (about 50 times higher), runoff depth and, at the same time, reduction in the depth of the infiltration. The increased urbanization of the catchment during the same time period, determined as $40 \%$, resulted in an increase in the maximum flow rate in the "Rosola" profile from an initial value of 0.409 to $7.861 \mathrm{~m}^{3} \cdot \mathrm{s}^{-1}$ (approx. 19 times higher), as well as outflow volume from 750.40 to $29,094.0 \mathrm{~m}^{3}$ (approx. 39 times higher).

- The effect of applying LID objects throughout the analyzed area was, in both cases, a reduction in the depth of surface runoff, outflow volume and, at the same time, an increase in the infiltration and retention depths, in response to a single rainfall event. The degree in which runoff was decreased depended on the type of applied objects, which were accounted for in the individual calculation scenarios, and the area they covered.

- The most significant reduction in surface runoff on the plot scale (approx. 99\%) occurred in the case of calculation scenarios calling for the application of infiltration trenches (LID3), as well as permeable layers of soil and gravel (LID5 and LID6). The amount of runoff was reduced to the level prior to urbanization of the plot. The above-listed scenarios accounted for the retention and infiltration of rainwater runoff from road surfaces, parking lots, and the roof of the shopping mall, as well as for creating a "green roof."

- The LID3 scenario, which called for creating infiltration trenches that take in the runoff of rainwater from roads, parking lots, and roof surfaces, without a doubt led to the largest increase in the depth of the infiltration on a plot scale (121.8\%). Infiltration depth was higher than for the state of land use in 1970, when the area consisted entirely of arable land.

- The lowest reduction of runoff depth in the analyzed catchment (20.7\%) and peak flow rate (approx. 16.1\%) were determined for scenarios that involved the application of permeable paved surfaces on some of the parking lots $(8.7 \%$ of the catchment area was modified) located in areas characterized by various types of land use.

- Scenarios that called for the application of infiltration trenches and permeable soil layers that take in surface runoff only from main roads and parking lots within the catchment revealed a significant reduction in surface runoff depth (28.0-29.6\%) and maximum flow rate (approx. 20\%). The analysis indicated that creating infiltration trenches also resulted in the highest increase in infiltration depth, i.e., $23.0 \%$.

- The most significant reduction in runoff/outflow was achieved by the combined application of objects of "permeable soil layer" and so-called "green roofs" (covering $12.1 \%$ of the catchment area), which enable runoff rainwater from main roads and parking lot surfaces to be absorbed into the ground, and rainwater to be retained on the surface of selected rooftops (scenario LID5). The reduction in the runoff depth and peak flow rate on the hydrograph amounted to 50.0 and $38.5 \%$, respectively, as compared to runoff from the catchment at the current state of its urbanization. The possibilities of realizing this scenario are, however, limited due to the difficulties connected with the construction of "green roofs."

\section{References}

1. CHANCELLERY OF THE SEJM. Water law, Act of 5 January 2011 on changes in the Water law act as well as other acts (OJ of 15 January 2011, no. 32, item 159). 2011 [In Polish]. 
2. NATIONAL CENTER FOR RESEARCH AND DEVELOPMENT (NCBiR). Natural environment, agriculture and forestry - BIOSTRATEG (Strategic program for scientific research and developmental work). 2013 [In Polish].

3. MARSALEK J., SCHREIER H. Innovation in Stormwater Management in Canada: The Way Forward, Water Quality Research Journal of Canada 44, (1), v-x, 2009.

4. BARSZCZ M. Innovative methods of managing rainwater in urbanized catchments. Gas Water and Sanitary Technology 1, 12, 2013 [In Polish].

5. ŻBIKOWSKI A., ŻELAZO J. Flood protection - difficulties and perspectives. Water Management 5, 98, 1994 [In Polish].

6. SAKSON G., ZAWILSKI M. Influence of applying LID objects on the functioning of urban sewerage systems. Gas Water and Sanitary Technology 6, 246, 2013 [In Polish].

7. GILROY K.L., MCCUEN R.H. Spatio-temporal effects of low impact development practices. Journal of Hydrology 367, 228, 2009.

8. ZIMMERMAN M. J., WALDRON M. C., BARBARO J. R., SORENSON J. R. Effects of Low-impact-development (LID) Practices on Streamflow, Runoff Quantity, and Runoff Quality in the Ipswich River Basin, Massachusetts - a Summary of Field and Modeling Studies. U.S. Geological Survey Circular 1361, 40, 2010.

9. AHIABLAME L.M., BERNARD A. E., INDRAJEET C. Effectiveness of low impact development practices in two urbanized watersheds: Retrofitting with rain barrel/cistern and porous pavement. Journal of Environmental Management 119, 151, 2013.

10. PYKE C., WARREN M. W., JOHNSON T., LAGRO J., SCHARFENBERG J., GROTH P., FREED R., SCHROEER W., MAIN E. Assessment of low impact development for managing stormwater with changing precipitation due to climate change. Landscape and Urban Planning 103, 166, 2011.

11. BŁASZCZYK W., STAMATELLO H., BŁASZCZYK P. Sewerage; Arkada Publishing: Warsaw, 1983 [In Polish].

12. POLISH NORMS PN-S-02204. Motor vehicle roads, Road Drainage; Polish Committee for Standardization, 1997 [In Polish].

13. BŁASZCZYK P. (Ed.) Principles of planning and designing sewage systems in urban-industrial agglomerations and large cities; Research Institute on Environmental Development; Warsaw, 1983 [In Polish].

14. SAWICKA-SIARKIEWICZ H., BŁASZCZYK P. Sewage equipment in urbanized areas. Technical and ecological conditions: Institute of Environmental Protection: Warsaw, 2007 [In Polish].

15. BARSZCZ M. Predicting maximum probable flows caused by heavy rainfall in the urbanized Służewiecki Stream catchment. Scientific Review Engineering and Environmental Sciences 4, (46), 3, 2009 [In Polish].

16. U.S. Department of Agriculture, Soil Conservation Service (USDA-SCS). National Engineering Handbook, Section 4, Washington, DC, 1975.

17. ROSSMAN L. A. Storm water management model user`s manual version 5.0. National Risk Management Research Laboratory, U.S. Environmental Protection Agency, Cincinnati, OH, 2010.

18. SŁYŚ D. Rainwater retention and infiltration; Publishing House of Rzeszow Technical University: Rzeszow, 2008 [In Polish].

19. GEIGER W., DREISEITL H. New means of draining rainwater, 1st ed.; Projprzem-EKO: Bydgoszcz, 1999 [In Polish].

20. BARSZCZ M. Normalized rainfall depth distributions during rainfalls in the area of an experimental catchment in Warsaw. Water-Environment-Rural Areas Vol. 12, 3 (39), 27, 2012 [In Polish].

21. DEBUSK K.M., WYNN K.M. Storm-water bioretention for runoff quality and quantity mitigation. Journal of Environmental Engineering 137, 800, 2011.

22. DREELIN E.A., FOWLER L., CARROLL C.R. A test of porous pavement effectiveness on clay soils during natural storm events. Water Res. 40, 799, 2006.

23. HAIFENG J., YUWEN L., SHAW L.Y., YURONG C. Planning of LID-BMPs for urban runoff control: The case of Beijing Olympic Village. Separation and Purification Technology 84, 112, 2012.

24. HUA-PENG Q., ZHUO-XI L., GUANGTAO F. The effects of low impact development on urban flooding under different rainfall characteristics. Journal of Environmental Management 129, 577, 2013.

25. CHAPMAN C., HORNER R.R. Performance assessment of a street-drainage bioretention system. Water Environ. Res. 82, 109, 2010. 
